\title{
Main Criteria for Models of Excellence in Health Care
}

\author{
Jasmina Tekićn, Vidosav D. Majstorović2 , Dejan Marković1, Angelina Nikodijević1, \\ Dragoslav Stamenković ${ }^{1}$ \\ 1School of Dentistry, University of Belgrade, Belgrade, Serbia; \\ 2Faculty of Mechanical Engineering, University of Belgrade, Belgrade, Serbia
}

\begin{abstract}
SUMMARY
Business excellence models have a long history of development of sixty years. Today, the business excellence model can be essentially classified as world's most famous models/awards for excellence (Japanese, American and European), the most popular national models of excellence (the Australian, British, German, French), as well as models of excellence companies (Siemens, Philips, Toyota). In the world today there are about 120 models of excellence. The best way to improve quality of health organizations that have systems of quality management is by application of the concept of total quality (TQM). This approach ensures the improvement of overall performance of health organizations, primarily the internal organization including management, resources, processes and human resources, health services and performance of business results. The market requires high quality products and services to improve the quality of life, or TQM excellence models in all areas of social subjects operations. It is a process that never ends, and knowing the nature of man who was never satisfied with achieved, that is main driving force for social development. We are witnesses today that some countries are introducing awards to organizations which succeeded in implementation of TQM and models of excellence for quality achievement. The development of a model of business excellence (BE) for dental health care is the main subject of the current study. The aim of this study is to present and analyze the existing criteria for product excellence and based on that, to define criteria for models of excellence for dental health care in Serbia.
\end{abstract}

Keywords: models of excellence; criteria for models of excellence; quality management; dental health care

\section{INTRODUCTION}

The quality of health care has been recognized as one of the most important characteristics of health care system both in public and private sector. Continuous quality improvement and patient safety is an integral part of everyday activities of health workers, health assistants and other employees in health system. It is a continuous process aimed to achieve higher level of success in work and more satisfied health care users and providers [1].

The quality of health care is the degree of correspondence with accepted principles and practices (standards). It is the degree of readiness to meet total needs of a patient and achieve desired outcomes (results) as well as compliance with the resource. It belongs to the group of terms that regard as adequacy, efficiency, comprehensiveness, equity, accessibility and satisfaction. Quality health care also considers the degree to which health care system and health services increase the likelihood of positive outcome.

Health in Serbia is very important social activity; there have been substantial structural changes during the transition process as the inevitable consequence of adaptation to new conditions. Contemporary concepts of health service organization require compliance with the modern life style and European Union regulations in health area. Changes in socio-economic relations inevitably lead to changes in the health sector primarily due to the number of innovations and applications of the latest practical experience, but also due to the changes within the market and transition. New legislation in the field of health care and health insurance will allow the rationalization of the health care system which main interest is satisfied patient [2]. This goal requires the provision of minimal cost, continuous improvement of quality of dental services and meeting the strategic goals of health care institutions that influence patient satisfaction.

Today, medical and dental health care requires high quality services aimed to improve the quality of health of patients and the concept of TQM through the model of excellence in health care. The beginning of TQM was the creation and implementation of a great number of methods and techniques to improve efficiency and effectiveness of business undertakings and all performance management to achieve world class performance and the appropriate model of excellence [3]. Excellence is defined as an excellent management practice in achieving world class performance results based on use of models of excellence. Excellence model is a practical management tool that should help health care organizations to carry out the measurements and determine their position in relation to the excellence. Excellence is dynamic goal, which is realistic, measurable and not too difficult to see, even 
when coordinates are constantly moving. The goals of excellence include the following coordinates: high level of performance of a health organization and comparison of results with domestic and foreign competition or the best in class, as well as long-term trends of improvements, breakthroughs and innovations in all aspects of operation. The principles and defined criteria (major) for models of excellence will be analyzed in this study, as the base for designing our excellence models in the field of dental health care.

The aim of this study is to present and analyze the existing criteria for product excellence and based on that, to define the criteria for models of excellence for dental health care in Serbia.

\section{CRITERIA FOR MODELS OF EXCELLENCE}

Business excellence has become the most powerful mean for achieving competitive advantage of companies, and quality management is the pathway for achieving excellent results in the future, as recognized by many companies in the world. Models of excellence differ in different situations. An overview of main criteria of the most popular models of excellence in the world which have served for designing our model are given in table 1.

\section{EUROPEAN MODEL OF EXCELLENCE FOR HEALTH CARE}

European model of excellence, in its current form, exists since 2001. It is defined on several levels as structured model for quality management in health care organization. Based on this model, established in 2004, the European prize has been awarded to the health organizations. The main criteria for this model are: leadership, human resources management, policy and strategy, other resources, processes, customer satisfaction, employee satisfaction, impact on society and business results. They represent a framework for development and implementation of the model of excellence [4].

Leadership analyzes the behaviour and actions of executive team and other managers of health organizations, also inspires, supports and promotes culture of total quality management (TQM). This, of course, requires evidence: how the executives of health organizations demonstrate their commitment to the implementation of TQM, support the improvement, and by their own efforts provide necessary support and resources, how they relate to patients, dentists, dental nurses, dental hygienists, other health care organizations as well as recognize and evaluate efforts and achievements of employees.

Along with establishment and development of health care organization, its policies and strategies are reviewed as well as how to perform actions.

People management is an analysis of how to use the full potential of employees. Therefore, in order to facilitate the development of employees' skills, it is very important to plan available resources and how to improve them.
Table 1. Criteria of excellence for selected models of excellence Tabela 1. Kriterijumi izvrsnosti za izabrane modele izvrsnosti

\begin{tabular}{|c|c|}
\hline \multirow{9}{*}{$\begin{array}{l}\text { European } \\
\text { model of } \\
\text { excellence } \\
\text { Evropski } \\
\text { model } \\
\text { izvrsnosti }\end{array}$} & $\begin{array}{l}\text { Leadership } \\
\text { Rukovodstvo }\end{array}$ \\
\hline & $\begin{array}{l}\text { Human resource management } \\
\text { Upravljanje ljudskim resursima }\end{array}$ \\
\hline & $\begin{array}{l}\text { Policy and strategy } \\
\text { Politika i strategija }\end{array}$ \\
\hline & $\begin{array}{l}\text { Other resources } \\
\text { Ostali resursi }\end{array}$ \\
\hline & $\begin{array}{l}\text { Processes } \\
\text { Procesi }\end{array}$ \\
\hline & $\begin{array}{l}\text { Client satisfaction } \\
\text { Zadovoljstvo korisnika }\end{array}$ \\
\hline & $\begin{array}{l}\text { Employee satisfaction } \\
\text { Zadovoljstvo zaposlenih }\end{array}$ \\
\hline & $\begin{array}{l}\text { Impact on society } \\
\text { Uticaj na društvo }\end{array}$ \\
\hline & $\begin{array}{l}\text { Business results } \\
\text { Rezultati poslovanja }\end{array}$ \\
\hline \multirow{7}{*}{$\begin{array}{l}\text { American } \\
\text { model of } \\
\text { excellence } \\
\text { Američki } \\
\text { model } \\
\text { izvrsnosti }\end{array}$} & $\begin{array}{l}\text { Leadership } \\
\text { Rukovodstvo }\end{array}$ \\
\hline & $\begin{array}{l}\text { Strategic planning } \\
\text { Strateško planiranje }\end{array}$ \\
\hline & $\begin{array}{l}\text { Focus on customer and market } \\
\text { Usmerenost na kupca i tržište }\end{array}$ \\
\hline & $\begin{array}{l}\text { Development of human resources management } \\
\text { Razvoj upravljanja ljudskim resursima }\end{array}$ \\
\hline & $\begin{array}{l}\text { Management processes } \\
\text { Procesi upravljanja }\end{array}$ \\
\hline & $\begin{array}{l}\text { Business results } \\
\text { Rezultati poslovanja }\end{array}$ \\
\hline & $\begin{array}{l}\text { Information and analyses } \\
\text { Informacije i analize }\end{array}$ \\
\hline \multirow{7}{*}{$\begin{array}{l}\text { Japanese } \\
\text { model of } \\
\text { excellence } \\
\text { Japanski } \\
\text { model } \\
\text { izvrsnosti }\end{array}$} & $\begin{array}{l}\text { Leadership } \\
\text { Rukovodstvo }\end{array}$ \\
\hline & $\begin{array}{l}\text { Social responsibility } \\
\text { Društvena odgovornost }\end{array}$ \\
\hline & $\begin{array}{l}\text { Strategic planning } \\
\text { Strateško planiranje }\end{array}$ \\
\hline & $\begin{array}{l}\text { Ability } \\
\text { Sposobnost }\end{array}$ \\
\hline & $\begin{array}{l}\text { Processes } \\
\text { Procesi }\end{array}$ \\
\hline & $\begin{array}{l}\text { Activities and results } \\
\text { Aktivnosti i rezultati }\end{array}$ \\
\hline & $\begin{array}{l}\text { Information management } \\
\text { Upravljanje informacijama }\end{array}$ \\
\hline \multirow{7}{*}{$\begin{array}{l}\text { Australian } \\
\text { model of } \\
\text { excellence } \\
\text { Australijski } \\
\text { model } \\
\text { izvrsnosti }\end{array}$} & $\begin{array}{l}\text { Leadership } \\
\text { Rukovodstvo }\end{array}$ \\
\hline & $\begin{array}{l}\text { Strategic planning } \\
\text { Strateško planiranje }\end{array}$ \\
\hline & $\begin{array}{l}\text { Knowledge and information } \\
\text { Znanje i informacije }\end{array}$ \\
\hline & $\begin{array}{l}\text { Staff } \\
\text { Zaposleni }\end{array}$ \\
\hline & $\begin{array}{l}\text { Focus on patient } \\
\text { Usmerenost na pacijenta }\end{array}$ \\
\hline & $\begin{array}{l}\text { Innovation and quality improvement } \\
\text { Inovacije i unapređenje kvaliteta }\end{array}$ \\
\hline & $\begin{array}{l}\text { Success and sustainability } \\
\text { Uspeh i održivost }\end{array}$ \\
\hline
\end{tabular}

An organization also manages other resources effectively and efficiently: financial, material, buildings, equipment, technology and intellectual property [4].

World Health Organisation (WHO) identifies, manages, reviews and improves its processes, sets up targets for improvement and enhancement using the latest technologies and innovations. WHO improves the quality 


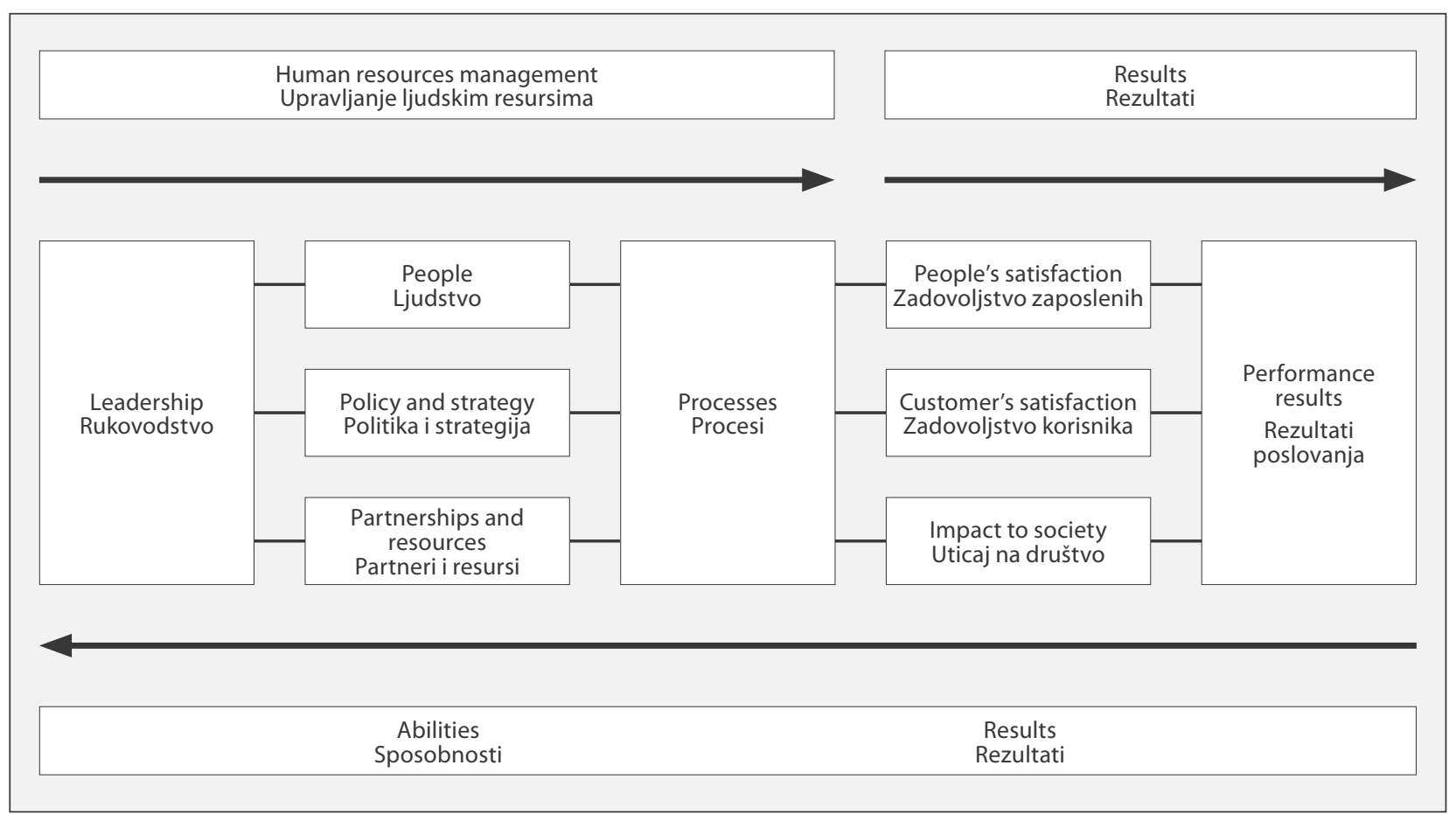

Scheme 1. General framework of the European Excellence Model Shema 1. Opšti okvir evropskog modela izvrsnosti

of health services to improve patient satisfaction, also improves working conditions for employees allowing them continuous medical training and use of modern technologies when working with patients. Satisfaction of patients and employees is measured, and the results are taken for corrective measures in order to increase satisfaction. WHO has an impact on the entire society and community, achieves planned goals and measure the financial effects of health care organizations (Scheme 1).

\section{AMERICAN MODEL OF EXCELLENCE FOR HEALTH CARE}

This model has been used since 1999. The main criteria for developing this model are: leadership, strategic planning, focus on customer and market, management of processes, information and analysis, personnel management and business results.

Strategic planning involves the development of plans aimed to achieve patients' needs and effective strategic and operational planning. The focus on users and market defines the method of determining their demands and expectations, as well as establishing and maintaining relationships with customers and users of products and services. Management of processes designs efficiency and effectiveness of processes and systems of quality assurance services. Information and analysis are the criteria that imply completeness of information and analysis of their usability as support in excellence and achievement in key performances and market success. Management of human resources considers putting efforts and succeeding in achieving full potential of workforce and creation of high performance organization. Business results - trends of actual performance and comparison with competitors in key business areas (customer satisfaction, finance, markets, products, human resources, partners, and other operations are expected consequences of this model) [5].

Top management of health organization should determine directions oriented to clear and visible values. Expectations and directions should be the balance of needs of all stakeholders. Their task is to design strategies and systems to achieve success, to encourage innovations and to build knowledge and personal skills of each employee. They motivate and inspire all employees in the health care system (HCS) to contribute to continuous learning and innovation, as well as to increase their personal creativity. They are the holders of responsibility in the management of WHO. They respect ethics, design vision and mission of WHO.

In order to further improve knowledge and capabilities of each employee, a health organization provides opportunities for continuous staff education, offering various pathways to success, but also listening about the needs of the entire health care system. All requirements of the HCS should be translated into programs and developmental experiences. The program should follow the latest technology in health care, both national and international. Organizational and personal learning is a prerequisite for achieving the highest levels of organizational performance. Continuous learning must be the part of everyday work at all organizational levels and the goal of meaningful change in quality of health care facilities. An organization designs programs of continuing medical education for employees with clear learning objectives according to the employees and health care organization needs with an efficient model to measure the achieved level of knowledge. To acquire new skills, employees should have train- 
ings and education available. That way, employees will become more satisfied and versatile in creative work environment [5].

The HCS user is the central part when designing the model of excellence. All user's needs should be determined. Also, an user should have the availability/accessibility to use health care services, with respect to ethics, privacy and confidentiality of information about the user.

\section{JAPANESE MODEL OF EXCELLENCE FOR HEALTH CARE}

The first model of a business excellence is Japanese model of excellence, which is based on Deming award for excellence in the application of the concept of Total Quality Control - TQC (statistical quality control). In gratitude to Deming and his contribution to the development of Japan, the Deming Prize established in 1951, is annually awarded to the companies (medium and small) which have developed a business improvement by applying concepts and methods of statistical quality management. The award is established on a 14-point improvement of quality and is awarded every year in November - the month of quality in Japan [6].

Checklist for implementation of Japanese model for the Deming Prize model involves: corporate policy, organization and administration, education and dissemination of knowledge and application. The elements that need to be checked are: profit management, cost management, managing suppliers, managing production processes, management resources, management tools, management of employees, labor relations and special programs for education. There are controls aimed to show how system deals with: collection and use of quality information, analysis, standardization, management and quality assurance.

This model of excellence is established in 1995, whiles the award for health organizations has been awarded since 2002. This model is based on: leadership, social responsibility, strategic planning, capacity, processes, activities and results [6].

\section{AUSTRALIAN MODEL OF EXCELLENCE FOR HEALTH CARE}

The excellence model is known as Australian Business Excellence Framework, established in 1999. Since 2003, it is in use for healthcare organizations. This model of excellence is based on the following criteria which define the framework of QM models for excellent organization. They are as follows:

- Leadership that includes: strategic direction, organizational culture, leadership throughout the organization and contribution to the environment and community;

- Strategy and Planning considers understanding of the business environment, planning and development and appliance of resources;

- Knowledge and information include the collection and interpretation of the data and information, integrating knowledge and its use in decision-making and knowledge management;

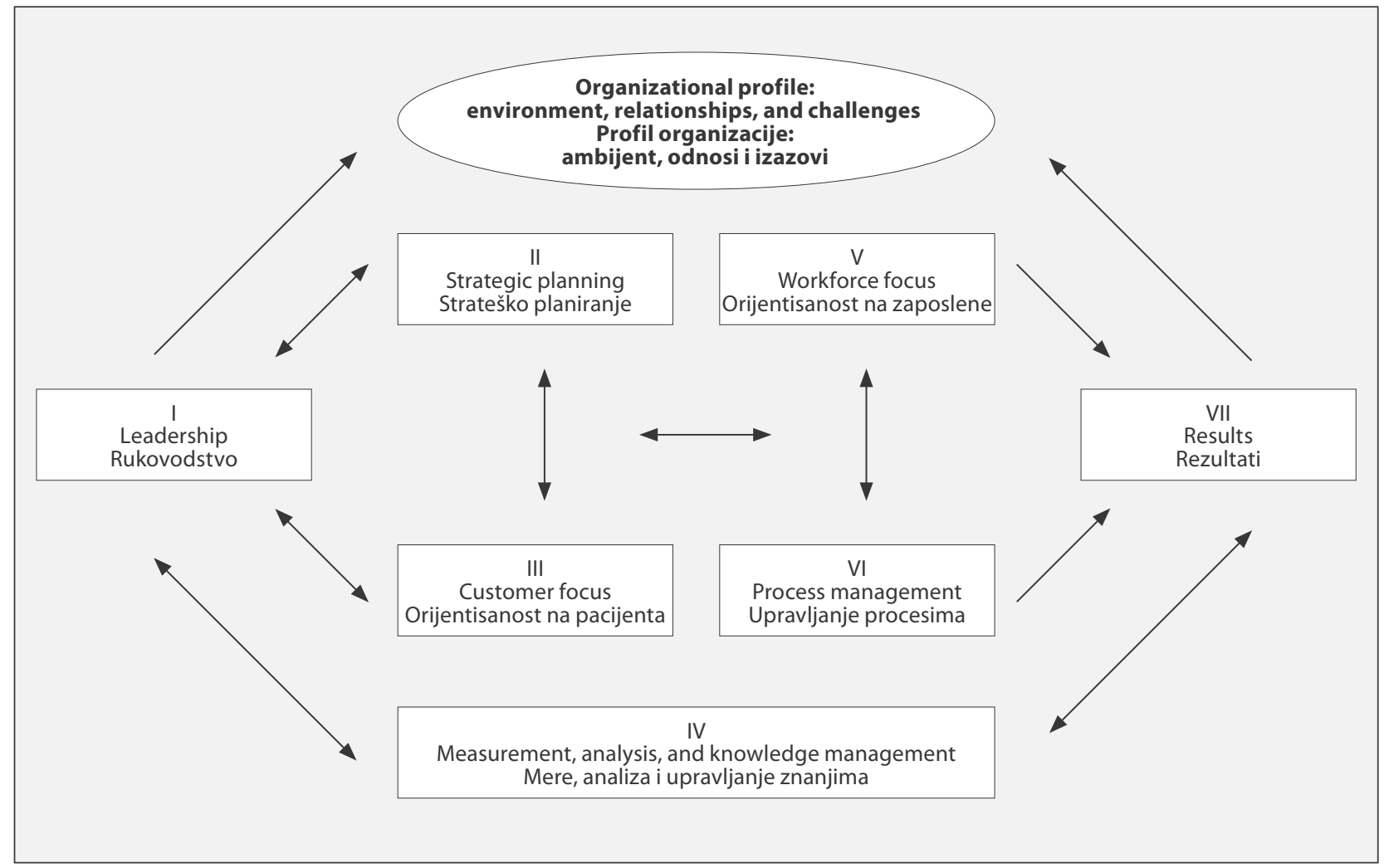

Scheme 2. Criteria MB model of business excellence (Source: Malcolm Baldrige National Quality Award Criteria for Performance Excellence, 1997) Shema 2. Kriterijumi MB modela poslovne izvrsnosti (Izvor: Malcolm Baldrige National Quality Award Criteria for Performance Excellence, 1997) 
Table 2. Review of criteria of excellence for selected models of excellence

Tabela 2. Pregled kriterijuma izvrsnosti za izabrane modele izvrsnosti

\begin{tabular}{|c|c|}
\hline $\begin{array}{l}\text { Model name } \\
\text { Naziv modela }\end{array}$ & $\begin{array}{l}\text { Principles of excellence } \\
\text { Principi izvrsnosti }\end{array}$ \\
\hline \multirow{9}{*}{$\begin{array}{l}\text { EFQM-EQA } \\
\text { (European } \\
\text { model of } \\
\text { excellence) } \\
\text { EFQM-EQA } \\
\text { (Evropski } \\
\text { model } \\
\text { izvrsnosti) }\end{array}$} & $\begin{array}{l}\text { Leadership } \\
\text { Rukovodstvo }\end{array}$ \\
\hline & $\begin{array}{l}\text { Human resource management } \\
\text { Upravljanje ljudskim resursima }\end{array}$ \\
\hline & $\begin{array}{l}\text { Policy and strategy } \\
\text { Politika i strategija }\end{array}$ \\
\hline & $\begin{array}{l}\text { Other resources } \\
\text { Ostali resursi }\end{array}$ \\
\hline & $\begin{array}{l}\text { Processes } \\
\text { Procesi }\end{array}$ \\
\hline & $\begin{array}{l}\text { Customer satisfaction } \\
\text { Zadovoljstvo korisnika }\end{array}$ \\
\hline & $\begin{array}{l}\text { Employee satisfaction } \\
\text { Zadovoljstvo zaposlenih }\end{array}$ \\
\hline & $\begin{array}{l}\text { Impact on society } \\
\text { Uticaj na društvo }\end{array}$ \\
\hline & $\begin{array}{l}\text { Performance results } \\
\text { Rezultati poslovanja }\end{array}$ \\
\hline \multirow{7}{*}{$\begin{array}{l}\text { MBNQA } \\
\text { (US model) } \\
\text { MBNQA } \\
\text { (Američki } \\
\text { model) }\end{array}$} & $\begin{array}{l}\text { Leadership } \\
\text { Rukovodstvo }\end{array}$ \\
\hline & $\begin{array}{l}\text { Strategic planning } \\
\text { Strateško planiranje }\end{array}$ \\
\hline & $\begin{array}{l}\text { Focus on customer and market } \\
\text { Usmerenost na kupca i tržište }\end{array}$ \\
\hline & $\begin{array}{l}\text { Development of human resource management } \\
\text { Razvoj upravljanja ljudskim resursima }\end{array}$ \\
\hline & $\begin{array}{l}\text { Management processes } \\
\text { Upravljanje procesima }\end{array}$ \\
\hline & $\begin{array}{l}\text { Performance results } \\
\text { Rezultati poslovanja }\end{array}$ \\
\hline & $\begin{array}{l}\text { Information and analysis } \\
\text { Informacije } i \text { analize }\end{array}$ \\
\hline
\end{tabular}

- Involvement and commitment is important for employees as well as results, development, health, safety and wellbeing;

- Focus on customer and market includes knowledge of customer and market, managing relationships with customers and presenting value of customers [7];

- Innovation, quality and improvement include the processes of innovation, processes with suppliers and partners, managing and improving processes and quality of products and services;

- Success and sustainability include indicators of success and sustainability (Scheme 2).

\section{THE FRAMEWORK FOR CRITERIA FOR MODEL OF EXCELLENCE IN DENTAL HEALTH CARE (DHC)}

Previous studies have defined the framework for developing model of excellence which includes: defining the excellence model in DHC, defining the main criteria and subcriteria, developing models for self-evaluation and models for assessing the maturity level of healthcare organization $[7,8,9]$. The basic element for the development of this model is the basic classification of medical institutions in our country that provide dental health care services: primary, secondary and tertiary. The framework

\begin{tabular}{|c|c|}
\hline $\begin{array}{l}\text { Model name } \\
\text { Naziv modela }\end{array}$ & $\begin{array}{l}\text { Principles of excellence } \\
\text { Principi izvrsnosti }\end{array}$ \\
\hline \multirow{7}{*}{$\begin{array}{l}\text { Japanese } \\
\text { model of } \\
\text { excellence } \\
\text { Japanski } \\
\text { model } \\
\text { izvrsnosti }\end{array}$} & $\begin{array}{l}\text { Leadership } \\
\text { Rukovodstvo }\end{array}$ \\
\hline & $\begin{array}{l}\text { Social responsibility } \\
\text { Društvena odgovornost }\end{array}$ \\
\hline & $\begin{array}{l}\text { Strategic planning } \\
\text { Strateško planiranje }\end{array}$ \\
\hline & $\begin{array}{l}\text { Ability } \\
\text { Sposobnost }\end{array}$ \\
\hline & $\begin{array}{l}\text { Processes } \\
\text { Procesi }\end{array}$ \\
\hline & $\begin{array}{l}\text { Activities and results } \\
\text { Aktivnosti i rezultati }\end{array}$ \\
\hline & $\begin{array}{l}\text { Information management } \\
\text { Upravljanje informacijama }\end{array}$ \\
\hline \multirow{7}{*}{$\begin{array}{l}\text { Australian } \\
\text { model of } \\
\text { excellence } \\
\text { Australijski } \\
\text { model } \\
\text { izvrsnosti }\end{array}$} & $\begin{array}{l}\text { Leadership } \\
\text { Rukovodstvo }\end{array}$ \\
\hline & $\begin{array}{l}\text { Strategic planning } \\
\text { Strateško planiranje }\end{array}$ \\
\hline & $\begin{array}{l}\text { Knowledge and information } \\
\text { Znanje i informacije }\end{array}$ \\
\hline & $\begin{array}{l}\text { Employees } \\
\text { Zaposleni }\end{array}$ \\
\hline & $\begin{array}{l}\text { Focus on patient } \\
\text { Usmerenost na pacijenta }\end{array}$ \\
\hline & $\begin{array}{l}\text { Innovation and quality improvement } \\
\text { Inovacije i unapređenje kvaliteta }\end{array}$ \\
\hline & $\begin{array}{l}\text { Success and sustainability } \\
\text { Uspeh i održivost }\end{array}$ \\
\hline \multirow{9}{*}{$\begin{array}{l}\text { Serbian } \\
\text { model of } \\
\text { excellence } \\
\text { for DHC } \\
\text { Srpski } \\
\text { model } \\
\text { izvrsnosti } \\
\text { za SZZ }\end{array}$} & $\begin{array}{l}\text { Leadership } \\
\text { Rukovodstvo }\end{array}$ \\
\hline & $\begin{array}{l}\text { Human resource management } \\
\text { Upravljanje ljudskim resursima }\end{array}$ \\
\hline & $\begin{array}{l}\text { Policy and strategy } \\
\text { Politika i strategija }\end{array}$ \\
\hline & $\begin{array}{l}\text { Other resources } \\
\text { Ostali resursi }\end{array}$ \\
\hline & $\begin{array}{l}\text { Processes } \\
\text { Procesi }\end{array}$ \\
\hline & $\begin{array}{l}\text { Customer satisfaction } \\
\text { Zadovoljstvo korisnika }\end{array}$ \\
\hline & $\begin{array}{l}\text { Employee satisfaction } \\
\text { Zadovoljstvo zaposlenih }\end{array}$ \\
\hline & $\begin{array}{l}\text { Impact on society } \\
\text { Uticaj na društvo }\end{array}$ \\
\hline & $\begin{array}{l}\text { Performance results } \\
\text { Rezultati poslovanja }\end{array}$ \\
\hline
\end{tabular}

for model of excellence in oral health care is based on criteria, presented and defined in Table 2.

The proposed model has nine criteria, and respects two basic facts: the achieved level of development of dental health care services in Serbia and further directions, as well as criteria and framework for the development of world-class model of excellence in health care. Their development has resulted from development of business excellence models, with respect to the specific features of these services, but also including some from the above criteria: American, European, Australian and Japanese model. The base of the model is American model of excellence in health care, while the other three are included in business system $[7,8,9]$.

Key features of the basic criteria of American model of excellence for exceptional health care organization are: their orientation to results, referring to the organizational performance such as output parameters for the quality 
of health services in relation to patients, financial and marketing outcomes, outcomes in relation to employees; effectiveness in operational results and outputs in relation to leadership, and results in relation to the society. The criteria are adaptive because their use does not depend on how the organization is structured, whether it has the department for planning, quality, etc. and that various departments in the same organization can be managed in different ways. This also means that the application of tools and techniques depends on the type, size and ability of employees to use them; the criteria are integrated into the key health services of the organization because they are adapted to the specific needs of health organization. These are different types of health services, patients and stakeholders are key buyers of health care facilities, the complex structure of leadership includes both professional and administrative structure of health organization and major medical services are delivered to the primary orientation on organizational processes, the criteria support systematic approach to maintaining and balancing the goals of health organisation.

The Republic of Serbia has the strategic goal to join the European Union; the most logical would be to design a model of excellence in line with European model. Therefore, this model adopts the principles common to all models of excellence included in this analysis [9].

\section{CONCLUSION}

Excellence in business is increasingly becoming business practice rather than the exception. For these reasons, excellence is not only the characteristics of business systems and organizations in industry and businesses, but increasingly of organizations in the field of services. The analysis is focused on services in dental health care, and its excellence is becoming imperative and good practice. Future research should be focused on developing other parts of this model, based on the principles defined in this paper. An important part will be to test the model of excellence in dental health care, in practice.

\section{REFERENCES}

1. Zakon o zdravstvenoj zaštiti. Službeni glasnik RS 107/05.

2. Zakon o zdravstvenom osiguranju. Službeni glasnik RS 107/05.

3. Minkman M. Performance improvement based on integrated quality management models: what evidence do we have? A systematic literature review. Int I for Qual Health Care. 2007; 19:90-104.

4. Celal S. The European experience: development of the EQA and future trends. In: Proceeding of Conference Global Competitiveness Through National Quality and Business Excellence Awards; Fiji, 2009. p.51-64.

5. Calingo L. The US Malcolm Baldrige national quality award - recent developments, processes, and applicability to the Asian setting. In: Proceeding of Conference Global Competitiveness Through National Quality and Business Excellence Awards; Fiji, 2009. p.21-39.

6. Ueda S. Japan Quality Award. In: Proceeding of Conference Global Competitiveness Through National Quality and Business Excellence Awards; Fiji, 2009. p.83-92.

7. Majstorović V. Model menadžmenta totalnim kvalitetom. Beograd: Mašinski fakultet; 2001.

8. Majstorović V. Integrisani menadžment sistemi - stanje razvoja i njihova primena. XVI konferencija o kvalitetu „Kvalitet, kompetentnost, kredibilitet, profit". Čanj 11-13. septembar 2006.

9. Tekić J, Majstorović VD, Marković D, Nikodijević A, Stamenković D. Quality management in dental health care: present and future development. Stomatološki glasnik Srbije. 2011; 58(1):35-43.

Received: 08/03/2011 • Accepted: 01/06/2011 


\title{
Glavni kriterijumi za modele izvrsnosti u zdravstvenoj zaštiti
}

\author{
Jasmina Tekić1, Vidosav D. Majstorović², Dejan Marković1, Angelina Nikodijević1, Dragoslav Stamenković1 \\ 'Stomatološki fakultet, Univerzitet u Beogradu, Beograd, Srbija; \\ ${ }^{2}$ Mašinski fakultet, Univerzitet u Beogradu, Beograd, Srbija
}

\begin{abstract}
KRATAK SADRŽAJ
Istorija razvoja modela poslovne izvrsnosti duga je šezdeset godina. Oni se u osnovi mogu klasifikovati na: najpoznatije svetske modele - nagrade za izvrsnost (japanski, američki i evropski), najpoznatije nacionalne modele izvrsnosti (australijski, britanski, nemački, francuski) i kompanijske modele izvrsnosti (Siemens, Philips, Toyota). Danas u svetu postoji oko 120 modela izvrsnosti. Najbolji način za unapređenje kvaliteta zdravstvene organizacije jeste primena koncepta „upravljanja ukupnim kvalitetom”. Ovaj pristup obezbeđuje unapređenje celokupnog poslovanja zdravstvene organizacije, prvenstveno interne organizacije, koja uključuje rukovodstvo, resurse, procese, kadrove, zdravstvene usluge i primenu poslovnih rezultata. Na tržištu se zahteva visok kvalitet proizvoda i usluga radi poboljšanja kvaliteta življenja, odnosno koncepta upravljanja ukupnim kvalitetom preko modela izvrsnosti poslovanja svih subjekata društva. To je proces bez kraja, poznavajući prirodu čoveka, koji nikada nije zadovoljan postignutim, što je osnovna pokretačka snaga razvoja društva. Svedoci smo da neke države uvode priznanja za organizacije koje su u određenom periodu napravile relevantan uspeh u primeni koncepta upravljanja ukupnim kvalitetom, odnosno u ostvarivanju modela izvrsnosti u postizanju kvaliteta. Ovde se istražuje razvoj modela poslovne izvrsnosti za oblast stomatološke zdravstvene zaštite. Cilj rada bio je da se predstave i analiziraju kriterijumi za model izvrsnosti, te na osnovu toga definišu kriterijumi modela izvrsnosti za stomatološku zdravstvenu zaštitu u Republici Srbiji.
\end{abstract}

Ključne reči: modeli izvrsnosti; kriterijumi modela izvrsnosti; upravljanje kvalitetom; stomatološka zdravstvena zaštita

\section{UVOD}

Kvalitet zdravstvene zaštite je jedna od najvažnijih odlika sistema zdravstvene zaštite, bilo da je reč o državnom ili privatnom sektoru. Stalno unapređenje kvaliteta i bezbednosti pacijenata sastavni je deo svakodnevnih aktivnosti zdravstvenih radnika i njihovih saradnika i svih drugih ljudi zaposlenih u zdravstvenom sistemu. Unapređenje kvaliteta je proces koji traje, a njegov cilj je dostizanje višeg nivoa uspešnosti u radu i većeg zadovoljstva korisnika i davalaca zdravstvenih usluga [1].

Kvalitet zdravstvene zaštite je stepen podudarnosti s prihvaćenim principima i praksom (standardom). To je i stepen spremnosti za zadovoljenje ukupnih potreba pacijenata i dostizanja željenih ishoda (rezultata), kao i usaglašenost s resursima. Kvalitet zdravstvene zaštite pripada onoj grupi pojmova koji podrazumevaju adekvatnost, efikasnost, sveobuhvatnost, pravičnost, dostupnost i zadovoljstvo. Kvalitetna zdravstvena zaštita podrazumeva stepen u kojem sistem zdravstvene zaštite i zdravstvena usluga povećavaju verovatnoću pozitivnog ishoda lečenja.

Zdravstvo u Srbiji je veoma značajna društvena delatnost, međutim, tokom procesa tranzicije, kao posledica neminovnog prilagođavanja novonastalim uslovima, došlo je do suštinskih strukturnih promena. Savremeni koncepti organizacije zdravstvene službe zahtevaju usklađivanje sa savremenim načinom života i usaglašavanje propisa u oblasti zdravstva s propisima Evropske Unije. Promene koje nastaju u društveno-ekonomskim odnosima neminovno dovode do promena u oblasti zdravstva, pre svega, zahvaljujući mnogobrojnim inovacijama i primeni najnovijih praktičnih iskustava, ali i promenama u okviru samog tržišta i tranzicije. Novi zakoni u oblasti zdravstvene zaštite i zdravstvenog osiguranja omogućiće racionalizaciju zdravstvenog sistema u čijem centru interesovanja se nalazi zadovoljan pacijent [2]. Ovakav cilj zahteva obezbeđenje minimalizacije troškova, stalnog poboljšanja kvaliteta stomatoloških usluga i postizanje osnovnih strateških ciljeva zdravstvenih ustanova koji utiču na zadovoljstvo pacijenta.
Danas se u medicinskoj i stomatološkoj zdravstvenoj zaštiti (SZZ) zahteva visok kvalitet usluga radi poboljšanja kvaliteta zdravlja pacijenata, odnosno koncepta „upravljanja ukupnim kvalitetom” preko modela izvrsnosti u zdravstvenoj zaštiti. Počeci stvaranja ovog koncepta bili su stvaranje i primena velikog broja metoda i tehnika za poboljšanje efikasnosti i efektivnosti poslovanja privrednih subjekata radi postizanja rezultata poslovanja menadžmenta svetske klase i odgovarajućeg modela izvrsnosti [3]. Izvrsnost se definiše kao izvanredna praksa menadžmenta u ostvarivanju rezultata poslovanja svetske klase zasnovanih na primeni modela izvrsnosti. Model izvrsnosti je praktičan alat upravljanja koji treba da pomogne zdravstvenim organizacijama da same obave merenja i utvrde gde se nalaze u odnosu na izvrsnost. Izvrsnost je relativan dinamički cilj koji je realan, merljiv i ne tako teško uočljiv, iako mu se koordinate neprestano pomeraju. Ciljevi izvrsnosti uključuju visok nivo poslovanja zdravstvene organizacije i rezultata u poređenju sa domaćom i stranom konkurencijom ili s najboljim u klasi, kao i pokazivanje dugoročnih trendova poboljšanja, proboja i inovacija u svim aspektima delovanja. Modeli izvrsnosti imaju svoje principe i definisane kriterijume koji će u ovom radu biti analizirani i opisani.

Cilj ovog rada je da se predstave i analiziraju postojeći kriterijumi za model izvrsnosti, te na osnovu toga definišu kriterijumi modela izvrsnosti za SZZ u Republici Srbiji.

\section{KRITERIJUMI ZA MODEL IZVRSNOSTI}

Poslovna izvrsnost je postala najjače sredstvo postizanja konkurentske prednosti kompanija, a upravljanje kvalitetom put koji obezbeđuje postizanje odličnih rezultata u budućnosti, što su prepoznale mnoge kompanije sveta. Modeli izvrsnosti se u različitim uslovima razlikuju. Pregled glavnih kriterijuma najpoznatijih modela izvrsnosti u svetu koji su nam poslužili kao osnova za projektovanje našeg modela dati su u tabeli 1 . 


\section{EVROPSKI MODEL IZVRSNOSTI ZA ZDRAVSTVENU ZAŠTITU}

Evropski model izvrsnosti u današnjem obliku postoji od 2001. godine. On je definisan u nekoliko nivoa kao strukturirani model za upravljanje kvalitetom u zdravstvenoj organizaciji. Model je ustanovljen 2004. godine i na osnovu njega se dodeljuje evropska nagrada za zdravstvene organizacije. Osnovni kriterijumi na osnovu kojih je ovaj model razvijen su: rukovodstvo, upravljanje ljudskim resursima, politika i strategija, ostali resursi, procesi, zadovoljstvo korisnika, zadovoljstvo zaposlenih, uticaj na društvo i rezultati poslovanja. Oni predstavljaju okvir razvoja i primene ovog modela izvrsnosti [4].

Rukovodstvo analizira ponašanje i akcije izvršnog tima i svih drugih rukovodilaca zdravstvene organizacije, inspiriše, podržava i promoviše kulturu upravljanja ukupnim kvalitetom. Naravno, za to je neophodan dokaz: kako rukovodioci zdravstvene organizacije pokazuju svoje angažovanje za primenu upravljanja ukupnim kvalitetom, kako podržavaju poboljšanje i ličnim angažovanjem obezbeđuju potrebnu podršku i resurse, odnosno kako su povezani sa pacijentima, stomatolozima, stomatološkim sestrama i higijeničarima i drugim zdravstvenim organizacijama, te kako prepoznaju i ocenjuju napore i dostignuća zaposlenih.

Sa formiranjem i razvojem zdravstvene organizacije preispituju se sopstvena politika i strategija i način na koji se planovi pretvaraju u akcije.

Kriterijum koji podrazumeva upravljanje ljudima bavi se analizom načina na koji zdravstvena organizacija koristi puni potencijal zaposlenih. Zato su važni planiranje raspoloživih resursa i njihovo poboljšanje, da bi se omogućio razvoj sposobnosti zaposlenih. Organizacija efektivno i efikasno upravlja i drugim resursima: finansijskim, materijalima, zgradama, opremom, tehnologijom i intelektualnom svojinom [4].

Svetska zdravstvena organizacija (SZO) prepoznaje, upravlja, preispituje i poboljšava svoje procese, postavlja ciljeve za unapređenje i poboljšanje primenom najnovijih tehnologija i inovacija. Ona poboljšava kvalitet zdravstvenih usluga, kako bi se poboljšalo zadovoljstvo pacijenta, kao i uslove rada zaposlenih, kojima omogućava kontinuirano medicinsko usavršavanje i primenu savremenih tehnologija u radu sa pacijentima. Zadovoljstvo pacijenata i zaposlenih se meri i na osnovu rezultata donose korektivne mere radi povećanja zadovoljstva. SZO ima uticaja na celokupno društvo i zajednicu, postiže planirane ciljeve i meri finansijske učinke organizacije zdravstvene zaštite (Shema 1).

\section{AMERIČKI MODEL IZVRSNOSTI ZA ZDRAVSTVENU ZAŠTITU}

Ovaj model se primenjuje od 1999. godine. Osnovni kriterijumi na kojima je razvijen jesu: rukovodstvo, strateško planiranje, usmerenost na korisnika i tržište, upravljanje procesima, informacije i analiza, upravljanje kadrovskim resursima i rezultati poslovanja.

Strateško planiranje podrazumeva razvoj planova usmerenih ka ostvarenju zahteva pacijenata i efikasno strateško i operativno planiranje. Usmerenost na korisnika i tržište definiše način određivanja zahteva i očekivanja korisnika i tržišta, odnosno način uspostavljanja i održavanja odnosa s kupcima i korisnicima proizvoda i usluga. Upravljanje procesima utiče na efikasnost i efektivnost procesa i sistem obezbeđenja kvaliteta usluga. Informacija i analiza je kriterijum koji podrazumeva celokupnost informacija i analizu njihove upotrebljivosti kao podrške u izvrsnosti i ostvarenju ključnih ciljeva i tržišnog uspeha. Upravljanje kadrovskim resursima podrazumeva uspešnost i uložen napor da se ostvari pun potencijal radne snage i da se stvori visok nivo poslovanja organizacije. Rezultati poslovanja se ogledaju u trendovima kretanja ostvarenih rezultata i poređenju sa konkurentima u ključnim poslovnim područjima (zadovoljstvo korisnika, finansije, tržište, proizvodi, ljudski resursi, partneri, operativa i dr. jesu očekivane posledice ovoga modela) [5].

Glavno rukovodstvo zdravstvene organizacije treba da utvrdi pravce orijentisane na jasne i vidljive vrednosti. Očekivanja i pravci treba da odslikavaju bilans potreba svih zainteresovanih strana. Njihov zadatak je i osmišljavanje strategije i sistema za postizanje uspeha, podsticanje inovacija i izgradnja znanja i ličnih sposobnosti svakog zaposlenog. Oni motivišu i inspirišu sve zaposlene u sistemu zdravstvene zaštite da doprinesu svom kontinuiranom učenju i inovativnosti, kao i povećanju lične kreativnosti u radu. Nosioci su odgovornosti u upravljanju SZO. Poštuju etiku, usvojenu viziju i misiju SZO.

Radi razvoja znanja i sposobnosti svakog zaposlenog, zdravstvena organizacija obezbeđuje mogućnosti da se osoblje kontinuirano obrazuje, nudeći im različite puteve ka uspehu i pri tom osluškujući potrebe celokupnog sistema zdravstvene zaštite. Sve zahteve ovog sistema treba pretočiti u odgovarajuće programe i razvojna iskustva. Program treba da prate najnovije tehnologije u oblasti domaće i svetske zdravstvene zaštite. Organizaciono i lično usavršavanje je uslov za postizanje najvišeg nivoa organizacionih rezultata poslovanja. Kontinuirano učenje mora biti deo svakodnevnog rada na svim organizacionim nivoima radi smislenih promena u oblasti kvaliteta rada zdravstvene ustanove. Organizacija dizajnira programe kontinuirane medicinske edukacije za zaposlene s jasnim ciljevima učenja u skladu s potrebama zaposlenih i zdravstvene organizacije s efikasnim modelom merenja postignutog nivoa znanja. Da bi zaposleni stekli nove veštine, organizacija ulaže u učenje kroz obrazovanje i obuku zaposlenih. Ovim zaposleni postaju zadovoljniji i svestraniji u kreativnom radnom okruženju [5].

U centru dizajniranja modela izvrsnosti je korisnik zdravstvene zaštite. Utvrđuju se i mere njegovih potreba. Omogućava mu se dostupnost korišćenja zdravstvenih usluga, pri čemu se poštuju etičnost, privatnost i tajnost podataka o korisniku zdravstvene zaštite.

\section{JAPANSKI MODEL IZVRSNOSTI ZA ZDRAVSTVENU ZAŠTITU}

Prvi model poslovne izvrsnosti bio je japanski i zasnivao se na Demingovoj nagradi za izvrsnost u primeni koncepta kontrole ukupnog kvaliteta (statističkog upravljanja kvalitetom). U znak zahvalnosti Demingu i njegovom doprinosu razvoju Japana, još 1951. godine uspostavljena je Demingova nagrada, koja se svake godine dodeljuje kompanijama (srednja i mala preduzeća) koje su postigle poboljšanje poslovanja primenom koncepta i metoda statističkog upravljanja kvalitetom. Nagrada se zasniva 
na 14 tačaka unapređenja kvaliteta i dodeljuje se svake godine u novembru - mesecu kvaliteta u Japanu [6].

Lista provere primene japanskog modela za Demingovu nagradu podrazumeva: korporacijsku politiku, organizaciju i administraciju, obrazovanje i širenje znanja i njihvou primenu. Elementi koje je potrebno proveriti su: upravljanje profitom, troškovima, dobavljačima, proizvodnim procesima, sredstvima i instrumentima, organizovanje zaposlenih, radni odnosi i programi obrazovanja. Postoje posebne provere čiji je cilj da pokažu kako se sistem odnosi na sakupljanje i korišćenje informacija kvaliteta, analize, standardizaciju, upravljanje i obezbeđenje kvaliteta.

Ovaj model izvrsnosti uspostavljen je 1995. godine, a nagrada za zdravstvene organizacije prema njemu dodeljuje se od 2002. Osnovni kriterijumi na kojima je razvijen ovaj model jesu: rukovodstvo, društvena odgovornost, strateško planiranje, sposobnost, procesi i aktivnosti i rezultati [6].

\section{AUSTRALIJSKI MODEL IZVRSNOSTI ZA ZDRAVSTVENU ZAŠTITU}

Ovaj model izvrsnosti je poznat pod nazivom „Australijski okvir za poslovnu izvrsnost“, a uspostavljen je 1999. godine. Za zdravstvene organizacije se primenjuje od 2003. godine. Model se zasniva na sledećim kriterijumima, koji definišu okvir modela upravljanja kvalitetom za dobru organizaciju:

- Rukovodstvo - podrazumeva strateško usmeravanje, organizacionu kulturu, rukovođenje celom organizacijom i doprinos životnoj sredini i društvenoj zajednici;

- Strategija i planiranje - podrazumeva razumevanje poslovnog okruženja, proces planiranja i razvoja i primenu resursa;

- Znanje i informacije - obuhvataju sakupljanje i interpretaciju podataka, integrisanje znanja i njegovo korišćenje u procesu donošenja odluka i stvaranje i upravljanje znanjem;

- Za zaposlene su važni uključenost, opredeljenost, rezultati, razvoj, zdravlje, sigurnost i dobrobit;

- Usmerenost na kupca i tržište - podrazumeva poznavanje kupca i tržišta, upravljanje vezama sa kupcima i opažanje vrednosti od strane kupca [7];

- Inovacije, kvalitet i unapređenja - uključuju procese inoviranja, procese sa isporučiocima i partnerima, upravljanje i unapređenje procesa i kvalitet proizvoda i usluga;

- Uspeh i održivost - obuhvataju indikatore uspeha i indikatore održivosti (Shema 2).

\section{DEFINISANJE OKVIRA ZA KRITERIJUME MODELA IZVRSNOSTI STOMATOLOŠKE ZDRAVSTVENE ZAŠTITE}

Ranija istraživanja su definisala okvir za razvoj modela izvrsnosti koji obuhvata: definisanje principa modela izvrsnosti za SZZ, definisanje glavnih kriterijuma i potkriterijuma, razvoj modela samoocenjivanja i razvoj modela za ocenu nivoa zrelosti zdravstvene organizacije za SZZ [7, 8, 9]. Osnovni element od kojeg počinje razvoj ovoga modela je osnovna klasifikacija zdravstvenih ustanova u našoj zemlji koje pružaju usluge SZZ, a to su primarna, sekundarna i tercijarna. Osnovu okvira modela izvrsnosti za SZZ čine kriterijumi koji su prikazani u tabeli 2.

Predloženi model ima devet kriterijuma i uvažava dve osnovne činjenice - dostignuti nivo razvoja usluge SZZ u Srbiji i pravce budućeg razvoja, kao i kriterijume i okvire razvoja svetski poznatih modela izvrsnosti za zdravstvenu zaštitu. Njihov razvoj je proistekao iz razvoja poslovnih modela izvrsnosti, uz poštovanje specifičnosti ove usluge, ali i uključivanja nekih kriterijuma iz analiziranih: američki, evropski, australijski i japanski model. Osnovu modela čini američki model izvrsnosti za zdravstvenu zaštitu, dok su ostala tri uključena kao procesni poslovni sistem [7, 8, 9].

Ključne odlike osnovnih kriterijuma američkog modela izvrsnosti jesu: 1) njihova orijentacija na rezultate, koji se odnose na organizacione rezultate poslovanja kao što su postignuti kvalitet zdravstvene usluge u odnosu na pacijenta i finansijski i marketinški ishodi u odnosu na zaposlene; 2) efektivnost procesa, uključujući operativne rezultate u odnosu na rukovodstvo; i 3) rezultati u odnosu na društvo. Kriterijumi su prilagodljivi, jer njihova primena ne zavisi od toga kako je organizacija strukturirana, da li ima odeljenja za planiranje, kakav je kvalitet itd., kao i to da se različitim odeljenjima u istoj organizaciji može upravljati na različite načine. Ovo takođe znači da primena alata i tehnika zavisi od tipa, veličine i sposobnosti zaposlenih da ih koriste. Kriterijumi su integrisani u ključne usluge zdravstvene organizacije zbog toga što se prilagođavaju specifičnim zahtevima zdravstvene organizacije. To su: različite vrste zdravstvenih usluga; pacijenti i interesne grupe su ključni kupci zdravstvene ustanove; složena struktura rukovodstva obuhvata kako stručnu, tako i administrativnu strukturu zdravstvene organizacije; najvažnije zdravstvene usluge se isporučuju s primarnom usmerenošću na organizacione procese; kriterijumi podržavaju sistemski pristup održavanju i uravnoteženju ciljeva zdravstvene organizacije.

S obzirom na to da je strateški cilj Srbije pridruživanje Evropskoj Uniji, najlogičnije bi bilo da je dizajniranje modela izvrsnosti u skladu s evropskim modelom. Zato su u ovom modelu usvojeni principi zajednički za sva četiri razmatrana modela izvrsnosti [9].

\section{ZAKLJUČAK}

Izvrsnost u poslovanju sve više postaje poslovna praksa, a ne izuzetak. Stoga ona nije samo odlika poslovnih sistema i organizacija u industriji i privredi, već sve više i organizacija iz oblasti usluga, u koje se ubrajaju i usluge SZZ. Buduća istraživanja bi trebalo usmeriti na razvoj ostalih segmenata ovog modela, polazeći od principa definisanih u ovom radu. Važan deo će biti i ispitivanje modela izvrsnosti za SZZ u praksi. 